\title{
The Generational Gap and its Impact on Employee Motivation
}

\author{
M.D.I. Eragani*, Prof. Prasadini Gamage \\ Department of Human Resource Management, Faculty of Commerce and Management Studies, University of \\ Kelaniya, Sri Lanka
}

*Corresponding Author: M.D.I. Eragani, Department of Human Resource Management, Faculty of Commerce and Management Studies, University of Kelaniya, Sri Lanka

\begin{abstract}
The purpose of this research paper is to assess the impact of $X$ and $Y$ generation difference on employee motivation in ABC Private Hospital. In this study, $X$ and $Y$ generation difference was taken as the independent variable and employee motivation was taken as the dependent variable and assess the impact of the generation difference on five motivation factors from the Herzberg Motivation Theory; Growth, Achievements, Job Itself, Recognition and Advancement Motivation. The main objective of the study is to assess the impact of $X$ and $Y$ generation difference on employee motivation and there are five specific objectives. Six hypothesis were developed in this study. The data was collected from 50 back office staff members from the hospital by using the convenient sampling technique. A structured questionnaire was distributed to collect primary data and the data was analyzed using the Independent Sample T Test. The study revealed that there is a difference of each generation's motivation factors. $X$ generation employees prefer Achievement motivation while the $Y$ generation employees prefer Job Itself motivation. It is recommended that the employer should have a sound knowledge on each generation's preference and should satisfy two distinct generations according to their preference in order to retain them for a long time.
\end{abstract}

Keywords: X generation, Y generation, Employee Motivation

\section{INTRODUCTION}

Every organization needs a satisfied workforce in order to achieve long term goals and objectives. So that organizations should focus their attention on transforming their working environments to motivate the workforce to engage in behavior that is consistent with their goals and objectives in order to survive in the market rivalry (Amar, 2004). There is a significant difference between motivating employees in the past and in the present (Agarwal et. al., 2001) since each generation have their own preference in the working environment. The organizations should not only concern on the employee's motivation but also should concern on the variances of the motivational factors between different generations. Failure in satisfying the above mentioned aspect causes to decrease the organizational effectiveness and as a result it creates unwanted working environments that declines the employees' contribution (Kian \& Yusoff, 2012).

Motivation is defined as the willingness to exert high levels of effort, toward organizational goals, conditioned by the effort's ability to satisfy some individual need (Saraswathi, 2011). Modern day most of companies focus their attention on motivating employees. There is a question regarding why companies allocate more money and other resources to motivate employees. Employee motivation is extremely important in that motivated employees are most often than not, able to produce efficient and effective result (Markova \& Ford 2011 as cited in Muriuki 2016). To understand how their employees, need to be motivated, employer should have a proper understanding on unsatisfied needs. The level of motivation affects all aspects of the overall performance of the organization. Among all content and process theories of motivation, Frederick Herzberg's well known Two-Factor Theory has introduced distinctive factors of employees' motivations. According to this theory employees' motivation factors into Extrinsic and Intrinsic. Extrinsic Factors also well known as job context factors are extrinsic satisfactions granted by other people for employees (Robbins, 2009). Intrinsic factors on the other hand are the one that actually contribute to employees' level of job satisfactions. It has widely being known as job content factors which aims to provide employees meaningful works that are able to intrinsically satisfy themselves by their works outcomes, responsibilities delegated experience learned, and achievements harvested (Robbins, 2009). 
Today's workforce is diverse, not only with respect to gender, ethnicity, culture and workstyles, but also with respect to age (Kapoor \& Solomon, 2011). We are living in a world of generations. The generation difference as discussed in many forums as usual a creation of human ingenuity and imagination which cannot be inevitable. Generation is defined as cohorts of individuals who were born and raised in the same time period and were thus exposed to similar social and historical environments (Murphy et al., 2010 as cited in Dwyer \& Azevedo, 2016). Crumpacker and Crumpacker (2007) stated that although not every member of a generation feels the impact of the historically import events equally and all the members of a specific generation are having a shared awareness on the events common to that generation. According to the changes in employee demographics, the workforce is now consisting with four generations: Traditionalists, Baby Boomers, Generation X and Generation Y (Kapoor \& Solomon, 2011). Generations are classified as above by considering the birth dates of individuals.

Several findings have identified preferences of Intrinsic and Extrinsic Motivation Factors for Generation X and Generation Y. From a research conducted by Ringer and Garma (2006), Generation $\mathrm{X}$ was have higher preference for intrinsic motivations compared to Generation Y. They are more likely to leave their jobs when another company provides better Extrinsic factors such as pay and benefits.

Then why there is difference of preference of motivation factors? The researcher is going to find whether there is a difference in motivational factors of $\mathrm{X}$ and $\mathrm{Y}$ generation. In order to continue the study, the researcher has selected ABC Private Hospital PLC as the population. It is a reputed private hospital in Sri Lanka. The sample is consisted with 55 back office staff members who come under Executive, Non-Executive, Assistant Manager and Manager level representing X and Y generation. The sample is the 55 employees while the population is the all staff of ABC Hospital.

\section{RESEARCH CONTEXT}

As Kian \& Yusoff (2012) Substantial changes on extents of satisfactions for both Intrinsic and Extrinsic Factors on Generation X and Generation $\mathrm{Y}$ respondents have being confirmed from statistical calculations. According to Denny et.al (2013) the factors that motivate Gen- Y students differ from those that motivated their Gen- X. Gursoy et.al (2008) said that employees from same generation are likely to share similar norms as their values and attitudes are influenced by the generation they belong to.

Under this situation the study was conducted based on the ABC Private Hospital PLC. It is one of the leading private hospital located in the Colombo region and it has near 1000 employees. The population is the total staff members of the ABC Private Hospital PLC.The workforce is diversified since it is consisted with people who are highly educated like Consultants and people who have less education level like Housekeeping employees. When considering the gender breakdown of the staff it has 359 male staff and 599 female staff. As a percentage it has $37 \%$ male staff and $63 \%$ female staff.

Table1: Staff Composition

\begin{tabular}{|l|l|l|l|l|l|}
\hline Managerial & Consultants & Medical \& Para - Medical & Operational & Admin & Total Staff Count \\
\hline 18 & 2 & 415 & 486 & 37 & 958 \\
\hline
\end{tabular}

Source: Annual Statistics Report-ABC Private Hospital 2018

Operational level employees are less educated and most of them could not read and write even. It is difficult to take a time from Medical staff. So that theresearcher has selected Managerial and Admin employees (back office staff) for this study though it has five categories of employees.

\section{Problem Statement}

Human resource is the most precious asset of an organization. Even though an organization has many tangible and intangible assets, the optimum usage from those assets cannot be taken alone. There should be a proper utilization of the human resource in order to gain the competitive advantage. Any organization has a diversified workforce regarding age, gender, race and any more. Although many organizations spend time and resources into achieving and encouraging diversity, many limit their definition of diversity to gender and ethnicity. Generational diversity is one of the unaddressed area in the workforce diversity. When considering different generations, they have their own characteristics which are originated from the birth. They have their own value system and their preferences are 
changed from one generation to another. There is a difference between the motivational factors of each generation. There are very few empirical researches have been carried out in Sri Lankan context to identify the impact of generational difference on motivational factors.

When referring the Annual Statistics Data of the ABC Private Hospital, it is visible that there is high Labor Turnover Rate (LTO) during the past few years. According to that the trend of high LTO can be shown by table 1.2 stated in below. The data were obtained from the Annual Statistics Report 2015, 2016, 2017.

Table2: Annual LTO Rates

\begin{tabular}{|l|l|}
\hline Year & LTO Ratio \\
\hline 2015 & $29 \%$ \\
\hline 2016 & $35 \%$ \\
\hline 2017 & $33 \%$ \\
\hline
\end{tabular}

Source: Annual Statistics Report-ABC Private Hospital 2018

Most of the resigned employees are in the age between 20-40 years. At the exit interview the employees were asked on the reason behind their resignation. Different aged people revealed different reason. They revealed that they have resigned due to the lack of recognition and promotion opportunities, insufficient salary and bad working conditions. Those are motivational factors and it ensures that there is an impact of the difference between each generation towards the motivational factors.

Even though the company provides different welfare activities to enhance motivation to their employees, it is useless unless they identify the preference of each age. So that it is essential to address the need of each generation's preference. There is a shortage in Sri Lankan literature regarding this issue. Therefore the current research fill the knowledge gap.

This research focuses on addressing following specific research questions:

- What is the impact of X, Y generation difference on employee motivation?

- What is the impact of X, Y generation difference on Growth Motivation?

- What is the impact of X, Y generation difference on Job itself Motivation?

- What is the impact of X, Y generation difference on Achievement Motivation?

- What is the impact of X, Y generation difference on Recognition Motivation?

- What is the impact of $\mathrm{X}, \mathrm{Y}$ generation difference on Advancement Motivation?

\subsection{Objectives of the Study}

\subsubsection{Main Objective}

- The main purpose of the study is to assess the impact of $\mathrm{X}, \mathrm{Y}$ generational difference on employee motivation.

\subsubsection{Specific Objectives}

- To assess the impact of X, Y generation difference on Growth motivation.

- To assess the impact of X, Y generation difference on Job itself motivation.

- To assess the impact of X, Y generation difference on Achievement motivation.

- To assess the impact of X, Y generation difference on Recognition motivation.

- To assess the impact of X, Y generation difference on Advancement motivation.

\section{LITERATURE REVIEW}

Motivation is the most important factor that determine employee performance and the retention of employees. According to Kian and Yusuf (2012) as cited evidence from Wregner and Miller (2003), motivation is described as something that energizes individuals to take actions and which is concerned with the decisions the individuals make as part of his or her goal oriented behavior. In recent, Saraswathi (2011) stated that motivation is the consent to give high level of effort to achieve organizational goals, conditioned by the effort's ability to satisfy some needs of individual. According 
to Fuller et.al. (2008), motivation is the person's strength, direction and persistence of efforts to attain a specific objective. Money is not the only motivator that an employee can inspire. There are other incentives which can also serve as motivators (Acar (2014) as cited in Tella, Ayeni \& Popoola 2007: 2).

The workplace motivation theories are classified as either process theory or content theory (Campbell et. al., 1970 as cited in Yusoff, Kian \& Idris (2013)). In the content theory, it highlights on factors and needs that boost and motivate employees' behavior as well as performance. On the other hand, process theory illustrates that employees' behavior are driven by their individual needs and employees are contented when their expectations and values are met in their job.

According to (Kian, T.S., \& Yusoff, W.F.W., 2012), among all content and process theories of motivation, Frederick Herzberg's well known Two-Factor Theory has presented distinctive factors of employees' motivations. Herzberg defined two factors named Motivation and Hygiene Factors which decides employee working attitudes and level of performance (Robbins, 2009). Motivation Factors are known as Intrinsic Factors that will increase employees' job satisfaction; while Hygiene Factors are known as Extrinsic Factors to prevent any employees' dissatisfaction. Herzberg fostered that satisfying Hygiene Factors will not necessary result in employees' job satisfaction.

When considering those factors separately, Extrinsic Factors are also well known as job context factors and these factors give direction for employers in creating a satisfactory working environment where employees feel contented. Extrinsic motivation can be defined as doing something because it leads to a divisible outcome. It means that outside reinforcement or rewards are earned from performing a task than actual enjoyment of the task (Acar, 2014). According to College (2009), Extrinsic factors such as money and pay rewards support employees to decide whether to stay in the job or not.

On the other hand Intrinsic factors are the one that contribute to employees' level of job satisfaction. It is known as job content factors that focuses on providing employees meaningful works that are able to inherently satisfy themselves by their works consequences, responsibilities delegated, experience gathered and achievements obtained ( Robbins S. P., 2009). Intrinsic Factors are very effective in creating and maintaining more long-lasting positive effects on employees' performance towards their jobs as these factors are human basic needs for psychological growth.

Table3: Intrinsic Factors (Motivators) in the workplace (According to Herzberg)

\begin{tabular}{|l|l|}
\hline Achievements & $\begin{array}{l}\text { This includes the personal satisfaction of completing a job, solving problems, and seeing } \\
\text { the results of one's efforts. }\end{array}$ \\
\hline Recognition & This is the recognition by others for a job well done or personal accomplishment. \\
\hline Work Itself & $\begin{array}{l}\text { The actual content of the job and its positive or negative effect upon the employee whether } \\
\text { the job is characterized as interesting or boring, varied or routine, creative or stultifying, } \\
\text { excessively easy or excessively difficult, challenging or non-demanding. }\end{array}$ \\
\hline Advancements & The opportunity for advancement or promotion based on one's ability. \\
\hline Growth & $\begin{array}{l}\text { This includes actual learning of new skills, with greater possibility of advancement within } \\
\text { the current occupational specialty as well as personal growth. }\end{array}$ \\
\hline
\end{tabular}

\section{1. $X$ and $Y$ Generation Difference}

Kupperschmidt (2000) defined generation as an identical group of people who share birth years, age, location and significant historical events that occurred during their life time. The groups are known to as cohorts whose members are bound to each other and sharing the life experiences they gathered during their life time and the cohort ages are influenced by generational markers (Kian \& Yusoff, 2012). The workplace is consisted with four generations since the past decades until now (Ching, 2012). They are, Traditionalists, Baby Boomers, Generation X (Gen X) and Generation Y (Gen Y). These generations represent four groups of people who were born in four different range of years. Traditionalists are the one who were born between 1925-1945.Acording to Ching 2012, they are known as World War II Generation since they have experienced the World War II. Baby boomers were born between 1946 -1964 and they have unpleasant life experiences relating to the post- World War II. Generation X are those who were born between 1965 -1980 and the Generation Y people were born after 1980. According to Ching (2012) as cited evidence from Kowske, Rasch and Willey (2010) suggested that there are significant differences between Gen X and Gen Y in terms of the job satisfaction and turnover intention. The study done by Kian and Yusoff (2012) concluded that there is 
a significant difference on extent of satisfaction for both Intrinsic and Extrinsic factors between Gen $\mathrm{X}$ and Gen Y. thus the researcher will be focusing on Gen X and Gen Y in the current study.

\subsection{Generation $X$}

As mentioned above Generation X people were born between 1965 -1980. According to Kian and Yusoff (2012) as cited evidence from Dougan et.al., (2008) stated that Generation X learnt from their elders that following company rules and regulations is least likely secure their jobs. During their childhood they saw the worries of the adults caused by recession, inflation and stagflation (Ching (2012) as cited evidence from Association of American Retired Persons (2007)). Kupperschmidt (2000) revealed that the Generation $X$ is the children of Boomers the workaholic parents and who inherited boomers' social debris. The role of women has also changed. Generation x grew up alone as latchkey kids and they faced the life independently (Glass, 2007).

The historical incidents which affected Generation $\mathrm{X}$ in their childhood caused to create identical traits and characteristics within them. According to Kupperschmidt (2000) Generation X are multitasking parallel thinkers that able to do several tasks in one time. Not only that but also they are risk takers and entrepreneurial. Gursoy et.al. (2008) Generation X employees seek work life balance. They are very keen on problem solving and prefer not to take extra work. Smola and Sutton, 2002 found that Generation X members may have more commitment towards their own career rather than the organization they work and prefer to work in an organization which values skill development, productivity and work life balance than status and tenure. According to Tay (2011), Generation X employees are more money-oriented and skeptical than the Boomers. According to Kian and Yusoff (2012) s cited evidence from Santos and Cox (2000) suggested that generation X like to work in a flexible working environment with high autonomy, interesting yet challenging work, and giving opportunity for career growth. They want to maintain a career security and increase the marketability through challenging jobs in which the employer provide on the job training to enhance the job related knowledge (Kupperschmidt, 2000). They prefer face-to face communication as the Baby Boomers (Ching, 2012). They like to talk to the superior directly instead of sending mails and waiting replies from them (Tay, 2011; Glass, 2007). Altimier (2006) found that much of the Generation X employees do not struggle job hopping and are less interested to remain long in an organization, but believe that with their sufficient and competitive capabilities, job hopping will provide higher promotion opportunities and higher salary. Asian Financial Crisis which occurred in 1997 was a remarkable incident that affected Generation X employees and they suffered from the limited job opportunities in their young age (Kian \& Yusoff (2012) as cited evidence from Lager (2006)).

\subsection{Generation $Y$}

Generation Y are the group of people who were born after year 1980. They are also known as Millenials. They are the youngest employees in the current labor force. In future they will be replacing the Baby Boomers who are going to retire in the next few years (Ching, 2012). When comparing to Generation X, Generation $\mathrm{Y}$ is much larger group and emerged during the period of economic growth and technological progress (Bristow et.al. 2011). According to Kian and Yusoff (2012) it is perceived that Generation Y employees are more cooperative and optimistic than their elders since they have high educational background or professional training. William (2008) revealed that most of them are having either a diploma.

Most of Generation Y members were grew up with the modern technology and therefore they were much more familiar with the mobile phones and other devices. They try to make network throughout social media and prefer to search new information by using internet rather than traditional newspaper or a book. So that Glass (2007) suggested that they are the first adapter since they easily embrace new gadgets and technological equipment.

In addition, generation $\mathrm{Y}$ are great team workers and showing a high favour in teamwork (Dougan et al., 2008) and prefer to follow directions as long as there is flexibility for them to get the work done (Gursoy et al., 2008). Their motivations rely much on good teamwork with their team members (Murphy, 2010). Since they experienced an equal status and opportunities to voice in schools' extracurriculums, they are also showing their capabilities in group activities, practicing instant communication and expecting feedback in their workplaces (Gursoy et al., 2008). 
According to the study done by Kian and Yusoff (2012), "Generation X and Y and their work motivation", it has been found that both $\mathrm{X}$ and $\mathrm{Y}$ generations show some differences in their Intrinsic and Extrinsic motivation factors. Not only that but also it suggested that generation cohorts have their own groups of characteristics, aspirations and workplace expectations that creates a difference in motivation factors.

As per the study conducted by Ching (2012), "The association between generation $\mathrm{X}$ and $\mathrm{Y}$ and intention to leave, it was conveyed the idea that the $\mathrm{X}$ and $\mathrm{Y}$ generations' expectation of motivational factors is different from each other.

\section{CONCEPTUAL FRAMEWORK}

Here in this study, the independent variable is the $\mathrm{X}$ and $\mathrm{Y}$ generation and the dependent variable is employee motivation. Growth, Job itself, Achievement, Recognition and Advancement is considered as the dimensions of employee motivation. The conceptual framework of the study is shown in the below figure.

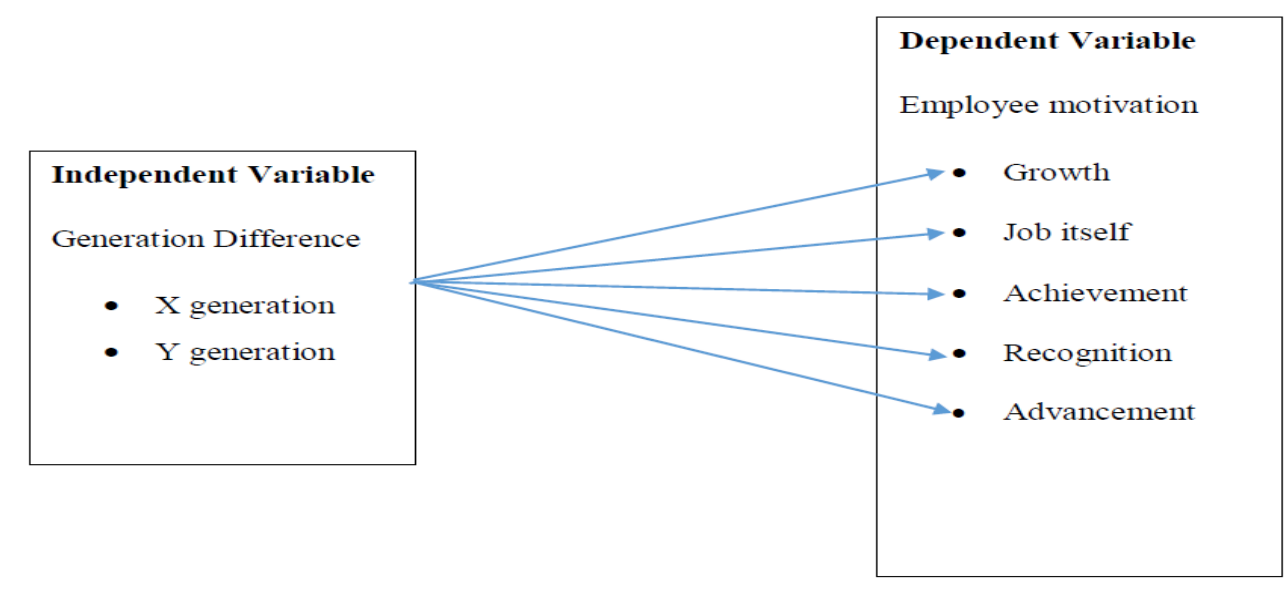

Figure1: Conceptual Framework

Source: Author, 2018

\subsection{Advancing of Hypotheses}

Having considered the evidences in literature recorded in chapter two of this research, $\mathrm{X}$ and $\mathrm{Y}$ generation is recognized as the independent variable and the employee motivation is identified as the dependent variable and based on that, following hypotheses have been advanced.

$\mathrm{H} 1$ : There is a significant difference of $\mathrm{X}$ and $\mathrm{Y}$ generation on Growth motivation.

$\mathrm{H} 2$ : There is a significant difference of $\mathrm{X}$ and $\mathrm{Y}$ generation on Job itself motivation.

$\mathrm{H} 3$ : There is a significant difference of $\mathrm{X}$ and $\mathrm{Y}$ generation on Achievement motivation.

$\mathrm{H} 4$ : There is a significant difference of $\mathrm{X}$ and $\mathrm{Y}$ generation on Recognition motivation.

$\mathrm{H} 5$ : There is a significant difference of $\mathrm{X}$ and $\mathrm{Y}$ generation on Advancement motivation.

H6: There is an impact of $\mathrm{X}$ and $\mathrm{Y}$ generation difference towards employee motivation.

\subsection{Overall Research Design}

This study is named as "The impact of the X and Y Generation difference on employee motivation". This is a quantitative type study which tries to find out the solution for the research problem of "What impact does the $\mathrm{X}$ and $\mathrm{Y}$ generation have on the employee motivation?" Since this study tries to find out the formulated hypotheses and the established relationships in the research model, this would be considered as an explanatory research.

Current study is a descriptive study. Mainly, the research will describe the data and characteristics and further, it will study the averages, mean values, frequencies and other statistical calculations. The research will be based on a quantitative explanatory research design.

Further, the required primary data will be collected at a single point of time and therefore, the study will be a cross sectional study. The interference of the researcher will be minimum in the study. Unit of analysis will be done at individual level. The study will be conducted among 55 back office 
employees of a reputed private hospital in Sri Lanka and the sample will be drawn through simple random sampling. Data will be collected pre- tested, standard questionnaire which has met the accepted standards of validity and reliability. Collected data will be analyzed though SPSS.

\subsection{Population}

The population of the study includes all the employees who come under $\mathrm{X}$ and $\mathrm{Y}$ generation (born between 1965-2000) of a reputed private hospital in Sri Lanka, out of which a representative sample will be taken.

\subsection{Sample and the Sampling Technique}

Simple random sampling would be used to select a representative sample. A total of 55 back office employees from the whole staff have been selected.

\subsection{Testing of Hypotheses}

\subsubsection{Sample Composition}

The questionnaire was distributed among 55 back office employees of the ABC Hospital PLC. Fifty two (52) has responded to the questionnaire and all the responses were eligible for the purpose of analysis through SPSS. As such, it resulted an $88 \%$ response rate out of the total sample.

In here, whether the respondent is belonged to $\mathrm{X}$ generation or $\mathrm{Y}$ generation is derived from age. $\mathrm{Y}$ generation is derived from the age between 20-37 and the $X$ generation is derived from age between 38-55. There are equal amount of $\mathrm{X}$ and $\mathrm{Y}$ generation respondents.According to the data collected, majority of the respondents are females and it is $59.6 \%$.

The highest educational attainment is categorized into five levels. Majority of the sample consists with post graduates. It is approximately $32.7 \%$ of the entire respondents. There were only $1.9 \%$ of employees attained up to secondary school.

Majority of the respondents have 3-5 years of working experience. It is approximately $28.8 \%$. There is only $11.5 \%$ respondents have $9-10$ years of working experience.

When considering the no of company working with, the majority of the respondents have been working with two companies. It is nearly $32.7 \%$. There are $3.8 \%$ of the respondents have been working with four companies.

Majority of the respondents are Executives and the percentage is 34.6\%. Assistant Managers and Managers are in same amount and the percentage is approximately $17.3 \%$.

There are $53.8 \%$ respondents from the sample have been working in this company between $0-2$ years. The least no of respondents have been working in this company for 9-10 years and as a percentage it is $1.9 \%$.

Table4: Testing of Hypotheses

\begin{tabular}{|c|c|c|c|c|c|c|c|c|c|c|}
\hline \multicolumn{11}{|c|}{ Independent Samples Test } \\
\hline & & \multicolumn{2}{|c|}{$\begin{array}{l}\text { Levene's Test for Equality of } \\
\text { Variances }\end{array}$} & \multicolumn{7}{|c|}{ t-test for Equality of Means } \\
\hline & & \multirow[b]{2}{*}{$\mathrm{F}$} & \multirow[b]{2}{*}{ Sig. } & \multirow[b]{2}{*}{$t$} & \multirow[b]{2}{*}{ df } & \multirow[b]{2}{*}{ Sig. (2-tailed) } & \multirow{2}{*}{$\begin{array}{c}\text { Mean } \\
\text { Difference }\end{array}$} & \multirow{2}{*}{$\begin{array}{l}\text { Std. Error } \\
\text { Difference }\end{array}$} & \multicolumn{2}{|c|}{$\begin{array}{l}95 \% \text { Confidence Interval of the } \\
\text { Difference }\end{array}$} \\
\hline & & & & & & & & & Lower & Upper \\
\hline \multirow[t]{2}{*}{ Growth } & $\begin{array}{l}\text { Equal variances } \\
\text { assumed }\end{array}$ & \multirow[t]{2}{*}{3.326} & \multirow[t]{2}{*}{.074} & -4.885 & 50 & .000 & -.65385 & .13384 & -.92268 & -38501 \\
\hline & $\begin{array}{l}\text { Equal variances not } \\
\text { assumed }\end{array}$ & & & -4.885 & 34.413 & .000 & -.65385 & .13384 & -.92573 & -.38196 \\
\hline \multirow[t]{2}{*}{ Job Itself } & $\begin{array}{l}\text { Equal variances } \\
\text { assumed }\end{array}$ & \multirow[t]{2}{*}{3.496} & \multirow[t]{2}{*}{.067} & -7.369 & 50 & .000 & -1.50000 & .20356 & -1.90885 & -1.09115 \\
\hline & $\begin{array}{l}\text { Equal variances not } \\
\text { assumed }\end{array}$ & & & -7.369 & 49.614 & .000 & -1.50000 & .20356 & -1.90893 & -1.09107 \\
\hline \multirow[t]{2}{*}{ Achievement } & $\begin{array}{l}\text { Equal variances } \\
\text { assumed }\end{array}$ & \multirow[t]{2}{*}{22.375} & \multirow[t]{2}{*}{.000} & 6.042 & 50 & .000 & 1.18269 & .19575 & .78952 & 1.57586 \\
\hline & $\begin{array}{l}\text { Equal variances not } \\
\text { assumed }\end{array}$ & & & 6.042 & 29.266 & .000 & 1.18269 & .19575 & .78250 & 1.58288 \\
\hline \multirow[t]{2}{*}{ Recognition } & $\begin{array}{l}\text { Equal variances } \\
\text { assumed }\end{array}$ & \multirow[t]{2}{*}{.472} & \multirow[t]{2}{*}{.495} & -.422 & 50 & .675 & -.10577 & .25051 & -.60893 & .39739 \\
\hline & $\begin{array}{l}\text { Equal variances not } \\
\text { assumed }\end{array}$ & & & -.422 & 49.038 & .675 & -.10577 & .25051 & -.60918 & .39764 \\
\hline \multirow[t]{2}{*}{ Advancement } & $\begin{array}{l}\text { Equal variances } \\
\text { assumed }\end{array}$ & \multirow[t]{2}{*}{10.459} & \multirow[t]{2}{*}{.002} & 3.937 & 50 & .000 & .73077 & .18563 & .35793 & 1.10361 \\
\hline & $\begin{array}{l}\text { Equal variances not } \\
\text { assumed }\end{array}$ & & & 3.937 & 33.004 & .000 & .73077 & .18563 & .35311 & 1.10843 \\
\hline \multirow[t]{2}{*}{ Motivation } & $\begin{array}{l}\text { Equal variances } \\
\text { assumed }\end{array}$ & \multirow[t]{2}{*}{2.664} & \multirow[t]{2}{*}{.109} & -.673 & 50 & .040 & .06923 & .10282 & -.27576 & .13730 \\
\hline & $\begin{array}{l}\text { Equal variances not } \\
\text { assumed }\end{array}$ & & & -.673 & 38.695 & .041 & -.06923 & .10282 & -.27727 & 13880 \\
\hline
\end{tabular}

Source: Survey Data, 2018 
The above table presented the result of t-test for $\mathrm{X}$ and $\mathrm{Y}$ generation motivation Factors. Given below is the analysis of each motivation factors.

Growth Motivation: The value of Levene's Test for Equality of Variance is 0.074 and is higher than 0.05 , then the row labeled Equal variances assumed are further being referred. Since results arrived from t-test has detected significant where sig (2-tailed) value $=0.000$ and $\mathrm{p}<0.05$, hence, the null hypothesis is rejected and alternative hypothesis is accepted. In conclusion, at significant level .05 there is a significant difference of $\mathrm{X}$ and $\mathrm{Y}$ generation on growth motivation.

Job Itself Motivation: The value of Levene's Test for Equality of Variance is 0.067 and is higher than 0.05 , then the row labeled Equal variances assumed are further being referred. Since results arrived from t-test has detected significant where sig (2-tailed) value $=0.000$ and $p<0.05$, hence, the null hypothesis is rejected and alternative hypothesis is accepted. In conclusion, at significant level .05 there is a significant difference of $\mathrm{X}$ and $\mathrm{Y}$ generation on Job itself motivation.

Achievement Motivation: The value of Levene's Test for Equality of Variance is 0.000 and is less than 0.05 , then the row labeled Equal variances not assumed are further being referred. Since results arrived from t-test has detected significant where sig (2-tailed) value $=0.000$ and $p<0.05$, hence, the null hypothesis is rejected and alternative hypothesis is accepted. In conclusion, at significant level .05 there is a significant difference of $\mathrm{X}$ and $\mathrm{Y}$ generation on Achievement motivation.

Recognition Motivation: The value of Levene's Test for Equality of Variance is 0.495 and is higher than 0.05 , then the row labeled Equal variances assumed are further being referred. Since results arrived from t-test has detected significant where sig (2-tailed) value $=0.675$ and $p>0.05$, hence, the null hypothesis is accepted while alternative hypothesis is rejected. In conclusion, at significant level .05 there is no significant difference of $\mathrm{X}$ and $\mathrm{Y}$ generation on Recognition motivation.

Advancement Motivation: The value of Levene's Test for Equality of Variance is 0.002 and is less than 0.05 , then the row labeled Equal variances not assumed are further being referred. Since results arrived from t-test has detected significant where sig (2-tailed) value $=0.000$ and $p<0.05$, hence, the null hypothesis is rejected and alternative hypothesis is accepted. In conclusion, at significant level .05 there is a significant difference of $\mathrm{X}$ and $\mathrm{Y}$ generation on Advancement motivation.

Employee Motivation: The value of Levene's Test for Equality of Variance is 0.109 and is higher than 0.05 , then the row labeled Equal variances assumed are further being referred. Since results arrived from t-test has detected significant where sig (2-tailed) value $=0.040$ and $p<0.05$, hence, the null hypothesis is rejected while alternative hypothesis is accepted. In conclusion, at significant level .05 there is a significant difference of $\mathrm{X}$ and $\mathrm{Y}$ generation on employee motivation.

\subsubsection{Ranking Motivation Factors}

Table5

\begin{tabular}{|l|l|l|l|l|l|l|}
\hline \multicolumn{2}{|l|}{ Age } & Growth & Job Itself & Achievement & Recognition & Advancement \\
\hline X generation & Mean & 3.9808 & 3.1346 & 4.6731 & 3.6923 & 4.4872 \\
\cline { 2 - 7 } & $\mathrm{N}$ & 26 & 26 & 26 & 26 & 26 \\
\cline { 2 - 7 } & $\begin{array}{l}\text { Std. } \\
\text { Deviation }\end{array}$ & .62419 & .70082 & .28080 & .83758 & .35566 \\
\hline \multirow{5}{*}{ Y gneration } & Mean & 4.6346 & 4.6346 & 3.4904 & 3.7981 & 3.7564 \\
\cline { 2 - 7 } & $\mathrm{N}$ & 26 & 26 & 26 & 26 & 26 \\
\cline { 2 - 7 } & $\begin{array}{l}\text { Std. } \\
\text { Deviation }\end{array}$ & .27596 & .76561 & .95781 & .96441 & .87716 \\
\hline
\end{tabular}

According to the table 1.5 there is a mean difference of motivational factors of generation $\mathrm{X}$. Achievement motivation was ranked in the highest place by showing the highest mean value of 4.6731. Then the Advancement motivation was ranked at the 4.4872 mean value.

Among the five motivational factors, Growth and Recognition were reported as third and fourth important factor to motivate Generation $\mathrm{X}$ while the least important factor is Job Itself with mean value of 3.1346

According to the table 1.5 there is a mean difference of motivational factors of generation Y. Growth and Job Itself motivation was ranked in the highest place by showing the highest mean value of 4.6346. Among the five motivational factors, Recognition and Advancement were reported as third 
and fourth important factor to motivate Generation $\mathrm{X}$ while the least important factor is Achievement with mean value of 3.4904 .

\section{FINDINGS}

The hypotheses were carried out using the results obtained from Independent Sample T Test analysis. As a whole, the results have proved that four hypotheses from the six hypothesis were accepted.

According to the descriptive statistics obtained, Achievement was considered to be as the vital dimension of Generation X, as it resulted the highest mean value of 4.6731. Simultaneously, Job Itself was the least significant dimension which resulted a mean value of 3.1346.

Job itself and Growth motivation were considered to be as the highest significant dimension of Generation Y, as it resulted the highest mean value of 4.6346. On the other hand Achievement was the least significant dimension for generation $\mathrm{Y}$ which resulted a mean value of 3.4904.

\subsection{Implications of the Study}

Employees are the life blood of an organization which gives the birth to its operations. Every organization has a diversified workforce with gender, age, religion, personality type, attitudes etc. Age difference is something inevitable and according to the age, it can be derived the generation they belong to. Most of the current workforce is consisted with generation X and generation $\mathrm{Y}$. They have unique characteristics based on the life experiences they felt.

As an employer, he or she has a responsibility to satisfy the employees and retain them for a long time within the company. In order to manage the staff turnover, understanding the antecedents of the employees' intention is very crucial. This study tries to provide in-depth measurement and analysis to help the employers to understand the Gen X and Gen Y in their staff. Based on the research results, it could provide the impact and idea to employers to better understand the desire in the workplace among the two generations. With the analysis, researcher hopes that it would be able to help the organizations to well-manage their employee turnover issues.

\section{CONCLUSION}

After some readings, research found that staff turnover is definitely a major challenge to employers. As discussed earlier, it creates a lot of unforeseen costs to an organization. Generation $X$ and Generation Y make up a large portion in labor market when Baby Boomers retire gradually in next few years. Hence, these two generations would become the important workforce in an organization.

The purpose of this research paper is to examine the impact of Generation $\mathrm{X}$ and Generation $\mathrm{Y}$ who are currently working in the ABC Private Hospital on their motivation factors. The findings showed that $\mathrm{X}$ and $\mathrm{Y}$ generation difference is significantly influencing employee motivation. It is because both of the generations were growing up in different time and they are shaped into different lifestyle, values, attitudes and they have their own characteristics.

The findings show that Generation $\mathrm{X}$ employees are referred to Achievement motivation while Generation Y employees are more preferred to Growth and Job Itself Motivation.

As an employer, in order to retain the employees for a long time period should have the ability to understand the motivation intention of employees according to their age group.

\section{RECOMMENDATIONS}

This study is mainly discussing about the impact of $\mathrm{X}$ and $\mathrm{Y}$ generation difference on employee motivation. Most of the time employers think the employees are resigned from their job since they are dissatisfied with the jobs. Therefore employers increase the benefit package more and more and think only about the financial side of the employees. However there may be any other reason beyond that. In fact, to manage the staff turnover in a multi-generation workforce, employers or managers could not manage their employees separately based on the generation. They should make these two generations interact well with each other. An employer can do several things to manage these generation difference in the workplace.

\section{- Understand Them}

Every employer should have a better understanding on their employees and they put into the employees' shoes to see the view point of employees. First of all the employer should aware on the composition of their workforce. After that the employer should understand the intention of employees. 
Their preferences are changed according to the generation they belonged. So that the employer should identify the needs of the employee and should accommodate the needs and wants of the employees.

\section{- Serve Their Need}

When the employer understands the staff expectation, he or she has a better know how to motivate the subordinates and he or she should better know how to motivate the subordinates to be more productive and committed by serving them their needs. By identifying the generation wise motivation factors, the employer can focus on the true need of the employee very easily.

\section{- Analyze Them from Time to Time}

Analyzing the human behavior should be part of HR functions. Individual is changing his or her attitude, behavior and expectation from time to time. So that HR department could conduct evaluation session to identify the issues with them. Some staff might be worried that organization would take action against if negative comments are given. Hence, the survey form must be filled in anonymously. By doing this, genuine answers could only be obtained.

However, this method does not allow HR to understand each of the staff but general views would be obtained. Nevertheless, HR could know the thinking of majority of the staff and come out with better policies to benefit both organization and employees.

\section{LIMITATION OF THE STUDY}

There are some limitations of this research paper. These limitations are highlighted in order to improve the future research in the relevant field.

First, researcher found difficult to gain the relevant articles especially related to the $\mathrm{X}$ and $\mathrm{Y}$ Generation employees' motivation. Hence, it would affect the comparison and interpretation between the current study and past studies.

Second, this research was conducted in relation to Generation $\mathrm{X}$ and Generation $\mathrm{Y}$, and yet it excludes other working generations in Sri Lanka. Hence, the results are not applicable to the entire workforce in the country.

Third, the dependent variables are limited to five factors. There are plenty of motivational theories and motivational factors have been studied since decades ago. This research paper chose only five factors from Hertzberg's Two Factor Theory. Other factors such as company culture, management style, Human Resources Management System (HRMS), reward systems, etc., have not been analyzed and yet these factors are also very important to influence the employee's intention to stay or leave their organizations.

Fourth, the survey questionnaires in this paper were distributed via questionnaire method. There is a challenge in collecting the data in this manner. Targeted respondents would have a doubt that it might be a research done by their employers. They had to clarify few times with the research to make sure the survey was not from their employers before they put the answers in the survey questionnaires. Some of them may play safe to give a favorable answers when asking about their opinions to the current organizations. Hence, the answers given might directly affect the accuracy of the research findings.

The limitations as highlighted above had been acknowledged and yet it will not affect the discussions of the study. It just provides a proposal for future research.

\section{REFERENCES}

[1] Acar, A. B. (2014). Do Intrinsic and Extrinsic Motivation Factors Differ for Generation X and Generation Y? International Journal of Business and Social Science.

[2] Agarwal, R., De, P., \& Ferratt, T.W. (2001). An Experimental Investigation of Turnover.

[3] Altimier, L. (2006). Leading a new generation. Newborn Infant Nurs. Rev.

[4] Bristow, D., Amyx, D., Castleberry, S. B., \& Cochran, J. J. (2011). A Cross- Generational Comparison of Motivational factors in a Sales Career Among Gen- X and Gen- Y College Students. Journal of Personal Selling \& Sales Management.

[5] Campbell, J.P., Dunnette, M.D., Lawler, E.E., \& Weick, K.E. (1970). Managerial Behaviour, Performance, and Effectiveness. New York: McGraw-Hill.

[6] Ching, G. S. (2012). The Association between Generation X and Y and Intention to leave. 
[7] College, S. (2009). The impact of intrinsic and extrinsic motivation on job choice in Generation Y. 4th Annual Siena College Student Conference in Busines, London.

[8] Cox, K., \& Santos, S. (2000). Workplace Adjustment and Intergenerational Differences between Matures ,Boomers and Xers. Nursing Economics.

[9] Crumpacker, M., \& Crumpacker, J. (2007). Succession Planning and Generational Stereotypes:Should HR Consider Age-Based Values and Attitudes A Relavnt Factor or A Passing Fad? Public Personnel Management.

[10] Denny, B., Douglas, A., Stephen B. C., \& James J. C. (2011). A Cross-Generational Comparison of Motivational Factors in a Sales Career Among Gen-X and Gen-Y. Journal of Personal Selling \& Sales Management.

[11] Dougan, G., Thomas, A. M., \& Christina, G. C. (2008). Generational Difference: An Examination of Work Values and Generational Gaps in the Hospitality Wokrforce. International Journal of Hospitality Management.

[12] Fuller, M.A., Valacich, J.S., \& George, J.F. (2008). Information Systems Project Management: A Process and Team Approach. New Jersey: Pearson Prentice Hall.

[13] Glass, A. (2007). Understanding generational differences for competitive success. Industrial and Commercial Training.

[14] Gursoy, D., Maier, T., \& Chi, C. (2008). Generational Differences: An Examination of Work Values and Generational Gaps in the Hospitality Workforce. International Journal of Hospitality Management.

[15] Kapoor, C., \& Solomon, N. (2011). Understanding and Managing Generational Differences in the Workplace. Worldwide Hospitality and Tourism Themes.

[16] Kian, T.S., \& Yusoff, W.F.W. (2012). GENERATION X AND Y AND THEIR WORK MOTIVATION. Business and Entrepreneurship.

[17] Kian, T.S., Yusoff, W.F.W., \& Idris,M.T.M. (2013). Herzberg's Two Factors Theory on Work Motivation: Does its work for todays environment? Global Journal of Commerce and Management Perspective.

[18] Kupperschmidt, B. (2000). Multigeneration Employees: Strategies for Effective. The Health Care Manager.

[19] More, H. W., Wegner, F. W., \& Miller, L. S. (2003). Effective Police Supervision. Cincinnati: Anderson Publishing Co.

[20] Muriuki, G. W. (2016). The effect of organizational rewards on motivation of generation Y employee: A case of Chase Bank LTD.

[21] Murphy, E. F., Gibson, J. W., \& Greenwood, R. A. (2010). Analyzing Generational Values among Managers and Non-Managers for Sustainable Organizational Effectiveness. SAM Advance Management Journal.

[22] Ringer, Allison, Garma \& Romana. (2006). Does the motivation to help differ between generation X and Y? in Australian \& New Zealand Marketing Academy. University of Otago, School of Business. Dunedin, N.Z.,.

[23] Robbins, S. P. (2009). Organizational Behaviour: International Version. Pearson Higher Education.

[24] Saraswathi, S. (2011). Study on Factors that Motivate IT and Non-IT Sector Employees: A Comparison. International Journal of Research in Computer Application and Management, .

[25] Smola, K.W. \& Sutton, C.D. (2002). Generational differences: revisiting generational work values for the new millennium. Journal of organizational Behavior.

[26] Tay, A. (2011). Managing Generational Diversity at the Workplace:Expectations and Perceptions of Different Generations of Employees. African Journal of Business Management.

[27] William, J. S. (2008). Generations X, Y, Z and the Others,. The Journal of the Households Goods Forwaders Association of America.

Citation: M.D.I. Eragani, Prof. Prasadini Gamage. "The Generational Gap and its Impact on Employee Motivation" International Journal of Managerial Studies and Research (IJMSR), vol 7, no. 8, 2019, pp. 26-36. doi: http://dx.doi.org/10.20431/2349-0349.0708003.

Copyright: (C) 2019 Authors. This is an open-access article distributed under the terms of the Creative Commons Attribution License, which permits unrestricted use, distribution, and reproduction in any medium, provided the original author and source are credited. 